\title{
Identitas Bekasi dalam Akun Media Sosial Komunitas
}

\author{
Rido Budiman \\ Universitas Islam 45, Bekasi, rido@englishunisma.org \\ M.Fakhran Al Ramadhan \\ Universitas Islam 45, Bekasi, fakhranpunk@yahoo.com
}

\begin{abstract}
Abstrak
Penelitian ini bertujuan untuk mengetahui bagaimana akun media sosial instagram komunitas mengkonstruksi, mengingatkan dan memberi tahu identitas kota bekasi bahwa "inilah bekasi" dengan memunculkan tengara kota Bekasi di dalam akun instagramnya. Selain menjadi komunitas yang mengeksplorasi tentang bekasi, kriteria foto-foto seperti apa dipilih untuk ditampilkan dalam akun instagram komunitas kota Bekasi. Metode yang digunakan dalam penelitian ini adalah etnografi, analisis wacana dan juga analisis visual, dimana hasil temuan data akan dideskripsikan dan kemudian ditinjau kembali untuk dianalisis dari pengamatan lapangan, proses wawancara, dan penelusuran pustaka. Rencana yang ingin dicapai dalam penelitian ini adalah untuk mengembangkan studi kajian budaya khususnya tentang studi kota dan media sosial. Penelitian berusaha untuk membuktikan bahwa ada kontestasi identitas kota dalam berbagai akun media sosial instagram yang berbeda dengan visi identitas kota yang dimunculkan oleh pemerintah kota Bekasi.
\end{abstract}

Kata Kunci: Identitas Kota; Studi Kota; Media Sosial.

\section{Abstract}

This study aims to find out how the community Instagram social media account constructs, reminds and informs the city identity of Bekasi that "this is Bekasi" by bringing up Bekasi city landmarks in its Instagram account. In addition to being a community that explores about Bekasi, what kind of photos are selected to be displayed in the Bekasi community Instagram account. The method used in this research is ethnography, discourse analysis and also visual analysis, where the data findings will be described and then reviewed for analysis from field observations, interview processes, and literature search. The plan to be achieved in this study is to develop a study of cultural studies specifically on city studies and social media. The research sought to prove that there were city identity contests in various Instagram social media accounts that were different from the vision of the city identity that was raised by the Bekasi city government.

Keywords: city identity; city studies; social media.

\section{PENDAHULUAN}

Manusia mengalami banyak peristiwa dalam kehidupannya tidak terkecuali penduduk kota. Dengan banyaknya peristiwa yang dialami, sebagai bagian dari ekosistem kota, penduduk kota mempunyai konstruksi ingatan tentang kejadian di kota. Bukan dibuat dengan sengaja, melainkan karena itu sudah menjadi bagian dari kegiatan sehari-hari. Kejadian merekam kota selain dengan ingatan, bisa dengan media representasi ${ }^{1}$

Foto adalah media representasi paling sempurna. Karena foto tidak menerjemahkan penampakan namun "mengutip" penampakan (Berger). Foto mengambil secara langsung peristiwa yang terjadi pada saat itu juga, karena peristiwa yang sama tidak terjadi dua kali.

\footnotetext{
${ }^{1}$ Stuart Hall. "The Work of Representation". In Representation: Cultural and Signifying Practices (London: Open University, 1997), 10.
} 
Proses kultural (melihat, mengintip) atas objek apa yang akan dipotret adalah sebuah konstruksi. Pembacaan atas peristiwa berlangsung cepat menghasilkan hasil foto yang tentunya mempunyai sebuah pesan. Hanya proses dari mulai pengoprasian kamera sampai menjadi sebuah gambar yang tidak bisa dicampuri manusia (teknikal). Faktor situasi sosial dan kehidupan objek maupun fotografer dapat menjadi argumen atau pengalaman sebagai cara menjelaskan kepada dunia. Sebagai contoh, jika ada sebuah foto tentang kota, akan muncul pertanyaan: apa yang menarik dari kehidupan kota? mengenai perihal tersebut, Henry Lefebre megemukakan bahwa kota adalah sebuah ekosistem didalam ruang sosial. Gagasan mengenai ruang sosial tersebut dapat tercapai apabila ruang tersebut sudah mampu bergerak sendiri. Artinya semua unsur dan elemen dalam ruang tersebut sudah dapat menjalankan perannya masing-masing dengan baik.

Berbeda dengan lanskap desa, di daerah pedesaan, terutama yang masih berada di daerah pedalaman, masih banyak ditemukan hal-hal yang masih berbau tradisional dan bersifat kental dengan kedaerahan (nature). Bangunan tinggi dan infrastuktur modern menjadi hal yang langka. Sebenarnya, penggambaran seseorang mengenai definisi umum sebuah kota, dilihat dari banyaknya jalan dan gedung-gedung pencakar langit seperti seolah menjadi tolak ukur kemodernan yang terdapat pada suatu wilayah, jejak peradaban dan ketegangan di kota lebih nyata daripada di pedesaan. Ini menegaskan kembali bahwa focus utama foto kota tidak terlepas dari unsur manusia dan kemampuan makhluk itu bernegosiasi dan bergerak dalam pergerakan yang dibangunnya.

\footnotetext{
${ }^{2}$ Walter Benjamin, "The Work of Art in the Age of Mechanical Reproduction". In Illumination
}

Kini lebih dari separuh penduduk dunia tinggal di perkotaan. Contohnya adalah kota Bekasi. Kota yang terletak di daerah Jawa Barat ini merupakan daerah Industri terbesar di Asia Tenggara. Dengan banyaknya kegiatan produksi yang terjadi di Bekasi, saya melihat fenomena kegiatan warga kotanya melalui suatu wadah kegiatan masyarakat yang berbentuk komunitas. Bekasi Banget merupakan sebuah komunitas yang bertujuan untuk mengeksplor segala hal yang terjadi di Bekasi. Melalui akun instagram @bekasi.banget, komunitas ini berusaha mengengenalkan ikon-ikon yang menjadi landmark Bekasi. Tidak hanya foto, akun@bekasi.banget juga memposting kegiatan-kegiatan yang berhubungan dengan anak muda Bekasi, misalkan acaraacara lomba atau seminar dan juga promosi tempat menarik di kawasan Bekasi.

Penggambaran kehidupan di kota Bekasi yang ditampilkan oleh komunitas bekasi banget melalui postingan foto-foto mereka di Instagram, komunitas ini memberikan gambaran tentang apa yang terjadi di kawasan Bekasi. Melalui komunitas ini, banyak anak muda di Bekasi seperti berlomba-lomba membuat foto sebagus mungkin tentang Bekasi.

Hausnya minat anak muda Bekasi untuk menghasilkan foto bagus dibarengi dengan teknologi kamera yang sekarang sangat mudah dibawa kemana-mana. Fenomena mengenai teknologi dalam seni fotografi pernah dibahas oleh Walter Benjamin yang mengatakan bahwa "mechanical reproduction represent something new"2. Hal yang menarik dari pemaparan tersebut adalah bagaimana foto dapat menonjolkan kehidupan manusia dalam ruang lingkup kawasan urban dan menghasilkan sesuatu yang baru.

Representasi visual yang dihasilkan sebuah foto, terutama foto tentang kota tidak

edited by Hannah Arendt. (New York: Schocken Books, 1969), 17. 


\section{Identitas Bekasi dalam Akun Media Sosial Komunitas}

hanya berfokus kepada suasana kota saja melainkan bagaimana foto tersebut bisa memuncukan identitas bahkan perilaku orang-orang yang tinggal di kota tersebut. Dari beberapa hal yang telah saya sebutkan, dapat dikatakan bahwa kawasan urban bisa menjadi tempat untuk pendokumentasian kehidupan masyarakat Bekasi modern. Khususnya di kota Bekasi.

Dari pemaparan diatas,terlihat bahwa bahwa memandang dan menilai sebuah kota bisa melalui media foto, melalui akun instagram @bekasi.banget, selain memperkenalkan objek dan ikon-ikon di Bekasi, terlihat juga adanya kontestasi dari para anak muda bekasi yang mencoba membuat foto sebagus mungkin tentang Bekasi. Sebagai kota yang baru berusia 19 tahun, identitas atau ciri khas asli Bekasi belum terlihat. Apa yang dihadirkan komunitas bekasi banget dalam foto akun instagramnya seperti berusaha mencoba memunculkan identitas tentang Bekasi dengan mengambil fokus objek-objek atau lokasi foto ikonik di kawasan bekasi.

Seperti kota London, misalkan hanya dengan foto pemandangan kota, namun jika ada bangunan dengan Big Ben tersebut, kita akan langsung mengetahui jika lokasi fotonya adalah kota London. Kehadiran figur Big Ben sebagai objek menjadi suatu penanda yang ikonik mengenai London. Pemandangan dan situasi yang dihadirkan dalam akun instagram @bekasi.banget seperti ingin memberikan pandangan ideal mengenai kawasan urban bekasi terutama melalui media foto agar para pegunjung akun intagram tersebut dapat melihat potensi kota bekasi. Hal seperti ini merujuk pada suatu cara mengingat dan mengimajinasikan suatu wilayah terutama daerah perkotaan. Dengan dinamika penduduk yang tinggi serta realita yang terjadi, komunitas bekasi banget mencoba memberi tahu dan mengingatkan kembali seperti apa wajah dari kota bekasi sebenarnya melalui fotofoto yang terpampang dalam akun instagram mereka.

Penelitian ini bertujuan untuk mengetahui bagaimana akun media sosial instagram komunitas mengkonstruksi, mengingatkan dan memberi tahu identitas kota bekasi bahwa "inilah bekasi" dengan memunculkan landmark kota Bekasi di dalam akun instagramnya. Selain menjadi komunitas yang mengeksplorasi tentang bekasi, kriteria foto-foto seperti apa dipilih untuk ditampilkan dalam akun instagram komunitas kota Bekasi. Metode yang digunakan dalam penelitian ini adalah etnografi, analisis wacana dan juga analisis visual, dimana hasil temuan data akan dideskripsikan dan kemudian ditinjau kembali untuk dianalisis dari pengamatan lapangan, proses wawancara, dan penelusuran pustaka. Rencana yang ingin dicapai dalam penelitian ini adalah untuk mengembangkan studi kajian budaya khususnya tentang studi kota dan media sosial. Penelitian berusaha untuk membuktikan bahwa ada kontestasi identitas kota dalam berbagai akun media sosial instagram yang berbeda dengan visi identitas kota yang dimunculkan oleh pemerintah kota Bekasi.

Dalam menganalisis identitas Kota Bekasi melalui foto, akan digunakan paparan dari Roland Barthes dalam The Photographic Message. Barthes memaparkan bahwa foto adalah suatu pesan yang ia sebut sebagai "paradoks"3. Berbagai gabungan dari gestur, ekspresi, warna maupun elemen lainnya terkadang hanya dimengerti oleh kalangan tertentu. Jadi, elemen yang membentuk sebuah foto tersusun sedemikian rupa, dengan demikian,

\footnotetext{
${ }^{3}$ Roland Barthes, "The Photographic Message" In Image, Text, Music (New York: Hill and Wang, 2009), 7.
} 
untuk mengetahui sebuah pesan dalam foto sebenarnya adalah suatu proses yang terstruktur. Paparan tersebut menjelaskan bahwa pesan yang terkandung dalam sebuah foto terdiri dari banyak unsur yang mempengaruhinya. Faktor gestur, mimic wajah ataupun latar dari tempat dan waktu dimana foto tersebut diambil memberikan kontribusi besar dalam pemaknaan sebuah foto.

Untuk meneliti media sosial secara etnografis saya menggunakan jurnal dari John Postill dan Sarah Pink ${ }^{4}$ yang menjelaskan bahwa ada beberapa metode yang bisa digunakan. Pertama dengan melihat sosial media sebagai tempat komunitas-komunitas tertentu untuk beraktivitas secara online maupun offline. Kemudian yang kedua dengan melihat social media sebagai tempat bagi para aktivis politik yang ruangnya dalam politik praktis dibatasi oleh penguasa. Rutinitas online dan offline kedua kelompok ini dilihat sebagai suatu data etnografi yang bisa dianalisis sesuai dengan pendekatan yang dipilih oleh peneliti.

Dalam penelitian Martin Gibbs ${ }^{5}$ yang menyajikan temuan dari studi penggunaan Instagram dan praktik penguburan yang dibagikan pada profil publik yang ditandai dengan '\#funeral'. Dia menemukan bahwa sebagian besar gambar yang diunggah dengan hashtag \#funeral sering dikomunikasikan dengan seseorang dalam keadaan emosional dan konteks afektif, dan membiarkan mereka memposisikan ulang pemakaman mereka Pengalaman di antara jaringan kenalan, teman, dan keluarga yang lebih luas. Dia membantah itu Berbagi foto melalui

\footnotetext{
4 Postill, John, and Sarah Pink. "Social Media Ethnography: The Digital Researcher in a Messy Web." Media International Australia 145, no. 1 (November 2012): 123-34. doi:10.1177/1329878X1214500114.

${ }^{5}$ Martin Gibbs, "Funeral and Instagram: death, social media, and platform vernacular"
}

Instagram menggemakan pergeseran yang lebih luas dalam peringatan dan Praktik pengamanan, beralih dari ritual formal dan melembagakan ke Informal dan personal, praktik vernakular. Akhirnya, kita anggap bagaimana Instagram 'Platform vernakular' terbentang dalam kaitannya dengan tradisi dan konteks kematian, berkabung, dan memorisasi penelitian ini memberikan kontribusi untuk pemahaman yang lebih luas tentang bagaimana platform

Vernaculars dibentuk melalui logika arsitektur dan penggunaan. Penelitian ini juga Secara langsung berkontribusi terhadap pemahaman tentang kematian dan media digital dengan memeriksa caranya Media sosial sedang dimobilisasi dalam kaitannya dengan kematian, perbedaan media yang berbeda Platform membuat, dan cara media sosial semakin terjalin dengan tempat, Kejadian, dan ritual berkabung.

Gibbs memaparkan lebih lanjut bahwa praktik dan teknologi media sosial sering menjadi bagian dari bagaimana penelitian etnografi. Peserta menavigasi dunia sosial, material dan teknologi mereka yang lebih luas dan berada dalam praktik etnografis yang sama. Hal ini menciptakan kebutuhan untuk mempertimbangkan bagaimana kemunculannya. Bentuk praktik etnografi berbasis media sosial dapat dipahami secara teoritis dan metodologis. Pada artikel ini Gibbs menanggapi secara kritis literatur yang ada. Tentang sifat internet sebagai situs etnografi, dengan menyarankan bagaimana caranya konsep rutin, gerakan, dan sosialitas memungkinkan kita untuk memahami pembuatannya Pengetahuan dan tempat etnografi media sosial.

\footnotetext{
Information, Communication \& Society, 2015.Vol. 18, No. 3, 255-268, http://dx.doi.org/10.1080/1369118X.2014.9871 52
} 


\section{Identitas Bekasi dalam Akun Media Sosial Komunitas}

Mary Madden dalam artikelnya Teens, Social Media, and Privacy ${ }^{6}$ memaparkan bahwa remaja berbagi berbagai informasi tentang diri mereka di situs media sosial; Memang situs itu sendiri dirancang untuk mendorong sharing informasi dan perluasan jaringan. Namun, beberapa remaja merangkul pendekatan publik sepenuhnya terhadap media sosial. Sebagai gantinya, mereka mengambil serangkaian langkah untuk membatasi dan memangkas profil mereka, dan pola pengelolaan reputasi mereka di media sosial sangat bervariasi sesuai dengan jenis kelamin dan ukuran jaringan mereka. Ini adalah salah satu temuan utama dari sebuah laporan baru berdasarkan survei terhadap 802 remaja yang meneliti manajemen privasi remaja di situs media sosial:

- Remaja berbagi lebih banyak informasi tentang diri mereka di situs media sosial daripada yang mereka lakukan di masa lalu. Untuk lima jenis informasi pribadi yang kami tentukan pada tahun 2006 dan 2012, masing-masing secara signifikan lebih mungkin dibagikan oleh pengguna media sosial remaja dalam survei terbaru kami.

- Penggunaan Twitter Remaja telah berkembang secara signifikan: $24 \%$ remaja online menggunakan Twitter, naik dari $16 \%$ di tahun 2011.

- Pengguna Facebook remaja biasa (median) memiliki 300 teman, sementara pengguna Twitter remaja biasa memiliki 79 pengikut.

- Diskusi kelompok terarah dengan remaja menunjukkan bahwa mereka telah memudar antusiasme terhadap Facebook,

Tidak menyukai meningkatnya kehadiran orang dewasa, orang-orang berbagi drama "drastis" yang berlebihan, dan stres

\footnotetext{
${ }^{6}$ Mary Madden, Teen, Social Media, and Privacy Pew Research Center, 2013.

${ }^{7}$ Tommy Firman, "Land Conversion and Urban Development in the Northern Region of West
}

Mereka tetap menggunakannya karena partisipasi merupakan bagian penting dari sosialisasi remaja secara keseluruhan.

- 60\% pengguna Facebook remaja menjaga profil mereka tetap pribadi, dan sebagian besar melaporkan tingkat tinggi Kepercayaan pada kemampuan mereka untuk mengelola pengaturan mereka.

- Remaja mengambil langkah lain untuk membentuk reputasi mereka, mengelola jaringan mereka, dan menutupi informasi yang mereka tidak ingin orang lain ketahui; 74\% pengguna media sosial remaja telah menghapus orang dari daftar jaringan atau teman mereka.

- Pengguna media sosial remaja tidak mengungkapkan kekhawatiran tingkat tinggi tentang akses pihak ketiga terhadap data mereka; Hanya 9\% mengatakan mereka "sangat" prihatin.

- Di Facebook, peningkatan ukuran jaringan berjalan seiring dengan variasi jaringan, berbagi informasi, dan manajemen informasi pribadi.

- Dalam cakupan pengalaman online yang luas, remaja cenderung melaporkan pengalaman positif daripada yang negatif. Misalnya, 52\% remaja online mengatakan bahwa mereka memiliki pengalaman online yang membuat mereka merasa nyaman dengan diri mereka sendiri.

Untuk jurnal yang membahas Bekasi sebagai kota ditemukan artikel dari Tommy Firman berjudul Land Conversion and Urban Development in the Northern Region of West Java, Indonesia ${ }^{7}$. Jurnal ini membahas dampak pembangunan ekonomi terhadap konversi lahan di Wilayah Utara Jawa Barat (WUJB) dan membahas implikasinya terhadap pembangunan perkotaan dan daerah. Perkembangan barubaru ini WUJB sebagian besar dipicu oleh

Java, Indonesia" Urban Studies Vol. 34, No. 7 (June 1997), pp. 1027-1046 
investasi domestik dan asing di kawasan ini, yang telah menyebabkan peningkatan permintaan tanah yang luar biasa. Selanjutnya, lahan pertanian utama telah terbagi dan dikonversi menjadi kawasan industri dan penggunaan lahan perkotaan lainnya. Konversi lahan pada dasarnya merupakan bagian normal dari proses pembangunan perkotaan, namun di WUJB, hal itu mencerminkan usaha tanah yang dilakukan oleh pengembang besar, yang cenderung bersifat spekulatif. Studi ini juga membahas beberapa reformasi kebijakan terkait lahan yang diperlukan untuk panduan konversi lahan.

Ditemukan juga jurnal yang membahas tentang kota di Indonesia yang mengkaji secara budaya yang berjudul Housing the Margin: Perumahan Rakyat and the Future Urban Form of Jakarta yang ditulis oleh Abidin Kusno ${ }^{8}$. Dalam jurnal ini Abidin Kusno memaparkan tentang analisis kebijakan perumahan nasional untuk kaum miskin kota dan pengaruhnya terhadap kewarganegaraan dan bentuk perkotaan di Jakarta. Ini melihat bagaimana program perumahan pro-kaum miskin diintegrasikan ke dalam pembaharuan perkotaan, sertifikasi tanah, dan "inisiatif kumuh bebas" kota. Artikel ini berpendapat bahwa program perumahan baru untuk orang miskin beroperasi dengan syarat neoliberalisme yang menuntut integrasi pasar tanah, perpindahan orang miskin ke pinggiran kota, dan perubahan geografi masa depan di Jakarta.

Jurnal lain yang membahas tentang kota di Indonesia yaitu berjudul The City as a Mirror: Transport, Land Use and Social Change in Jakarta yang ditulis oleh Ria Hutabarat Lo9. Artikel ini membahas polapola historis transportasi dan pengembangan

\footnotetext{
${ }^{8}$ Abidin Kusno, "Housing the Margin: Perumahan Rakyat and the Future Urban Form of Jakarta" Indonesia No. 94 (October 2012), pp. 23-56
}

penggunaan lahan di Jakarta dengan maksud untuk memahami makna pembangunan yang lebih besar dalam konteks ini. Makalah ini menggunakan analisis arsip dan wawancara kebijakan untuk melacak teori dan praktik pembangunan nasional dan perkotaan dari akhir periode kolonial sampai pertengahan tahun 1990an. Kesinambungan yang nyata dalam pengembangan jalan utama, koridor pergerakan barang dan ruang arus diselidiki sehubungan dengan klaim kebijakan fundamental dan perubahan sosial selama periode ini. Selain itu, pergeseran penyediaan sarana transportasi umum dan pejalan kaki diselidiki dalam hal proses kontestasi sosial dan resolusi yang lebih luas. Analisis tersebut menyoroti hubungan antara kebijakan transportasi dan penggunaan lahan dan pandangan ekonomi, politik dan sosial yang lebih luas. Hal ini juga menunjukkan bahwa, terlepas dari kemunculan perubahan ideologis dan pergolakan sosial yang mendasar, ada kontinuitas dalam pembangunan yang menyarankan pemeliharaan hubungan sosial di Jakarta. Sejauh ini belum ditemukan artikel jurnal ilmiah yang secara spesifik membahas tentang kota Bekasi sehingga diharapkan penelitian ini dapat menjadi pionir penelitian kajian budaya yang khusus membahas fenomana dan permasalahan di daerah ini.

\section{HASIL DAN PEMBAHASAN}

Akun Instagram Bekasi banget banyak memposting foto-foto yang berhubungan dengan Bekasi. Objek foto yang dipilih tidak hanya orang-orang Bekasi tetapi juga tengara yang hadir di Bekasi. Salah satunya adalah jembatan KH Noer Alie atau lebih populer dengan sebutan jembatan summarecon. Jembatan atau istilah

\footnotetext{
${ }^{9}$ Ria Hutabarat Lo, "The City as a Mirror: Transport, Land Use and Social Change in Jakarta", Urban Studies Vol. 47, No. 3 (March 2010), pp. 529-555
} 


\section{Identitas Bekasi \\ dalam Akun Media Sosial Komunitas}

yang lebih populernya flyover ini secara fungsional adalah sebagai penghubung antara pusat kota Bekasi dengan daerah Bekasi Utara yang dibatasi oleh empat jalur rel kereta api. Karena padatnya lalu lintas kereta di jalur ini, kendaraan bermotor sering terjebak dalam kemacetan yang panjang dan lama sehingga menghambat mobilitas penduduk Bekasi Utara yang merupakan sebuah daerah residensial yang padat bagi para pekerja komuter Jakarta. Berkat posisi yang tinggi sehingga lanskap kota terlihat jelas dan gampang diakses oleh warga Bekasi, tempat ini sering dijadikan latar foto untuk di upload di media sosial salah satunya di Instagram. Aktivitas Car Free Day (CFD) setiap hari minggu di jembatan ini merupakan salah satu latar favorit di akun @explorebekasi yang merupakan salah satu akun komunitas yang diteliti. Contohnya foto dari akun @kudaliarock, @bondandewa, @febridahara dan banyak lagi banyak menggunakan objek orang beraktivitas jalan pagi dan bersepeda di jembatan ini sebagai latarnya. Tidak hanya sebagai latar, beberapa akun seperti @arfyanta dan @faqihar menjadikan jembatan ini sebagai objek utama. Dengan desainnya yang modern dan berbeda dari flyover lainnya serta aktivitas CFD yang berlangsung setiap hari minggu yang diabadikan lewat foto akun media sosial terlihat ada konstruksi identitas kota yang modern yang dibangun. Identitas kota besar yang identik dengan kemacetan dan bangunan yang padat sehingga meminimkan aktivitas olahraga warga, dengan adanya jembatan dan CFD ini muncul pemaknaan baru bahwa identitas kota harus mempertimbangkan aspek kesehatan jiwa dan raga warganya.

Tengara berikutnya yang sering dijadikan objek foto di Bekasi adalah Stadion Patriot yang berada di pusat kota tepatnya di Jalan Jendral Ahmad Yani. Stadion ini telah berdiri sejak 1980 dan mengalami renovasi besar-besar pada tahun
2012 hingga berstandar internasional dengan desain yang unik dan ikonik sehingga sering dijadikan objek favorit para instagrammers. Dari foto-foto yang muncul di akun Bekasi banget maupun di Explore Bekasi, tempat ini menjadi favorit bagi instagrammer yang memiliki drone dan menggemari fotografi udara. Hal ini terlihat di akun instagram bekasi banget lewat kiriman foto dari akun @ pramramon bahkan tidak hanya menggunakan drone saja ada salah satu akun yang mengirim foto stadion ini dari sudut pandang pesawat komersial yang ditumpanginya. Penggunaan drone untuk fotografi merupakan hal yang hanya sedikit orang bisa melakukannya karena mahalnya alat ini dan perlunya keahlian khusus untuk mengoperasikannya. Sehingga orang-orang yang memiliki kemampuan finansial dan keahlian dalam hal ini memunculkan pemaknaan identitas yang eksklusif hanya dimiliki oleh segelintir orang. Pemaknaan identitas yang eksklusif ini diakui eksistensinya dalam komunitas ini dengan banyaknya foto drone yang terpilih dalam kiriman Bekasi of the day. Admin sosial media komunitas ini dengan membuat kiriman tersebut secara sadar maupun tidak ingin membangun identitas kota Bekasi yang indah secara fotografis.

Lewat kiriman yang menyertakan Stadion Patriot, akun Bekasi Banget terlihat ingin membangun identitas kebanggaan terhadap kota. Hal ini terlihat dengan kalimat yang menyertai foto ini "Bekasi merupakan legenda. Legenda yang harus kita jaga. Karena kalau bukan kita siapa lagi?”. Kata legenda apabila ditinjau dari sudut kebahasaan menurut Kamus Besar Bahasa Indonesia (KBBI) ada tiga makna. Makna pertama adalah cerita rakyat pada zaman dahulu yang ada hubungannya dengan peristiwa sejarah. Makna kedua adalah tokoh terkenal dan makna ketiga adalah keterangan atau penjelasan pada peta. Legenda yang dimaksudkan oleh kalimat postingan ini lebih mengena dengan makna 
pertama yaitu Bekasi memiliki peristiwa sejarah yang penting. Apabila dihubungkan dengan foto yang menampilkan Stadion Patriot peristiwa sejarah yang berhubungan dengan tempat ini adalah perang kemerdekaan Indonesia terhadap Belanda dan Jepang yang pernah berlangsung di daerah ini pada tahun 1940an. Peristiwa ini banyak diabadikan dalam bentuk tengara salah satunya penamaan stadion ini sebagai Patriot yang apabila ditelusuri dalam KBBI bermakna "pencinta (pembela) tanah air". Selain itu juga ada peristiwa sejarah lain yang berhubungan Bekasi yaitu dibangunnya kanal Candrabhaga oleh Raja Purnawarman dari kerajaan Tarumanegara pada abad ke 5 Masehi. Sehingga penamaan stadion ini menjadi Patriot Candrabhaga untuk lengkapnya. Dari segi penamaan ini terlihat bahwa ada usaha untuk membangun ingatan kolektif warga kota Bekasi bahwa kota ini memiliki sejarah yang panjang dan penting di Indonesia. Tetapi konstruksi identitas sebagai kota yang bersejarah ini apabila dilihat dari komentar-komentar terhadap postingan ini terlihat seperti gagal memahami konteks kata legenda yang menyertainya. Mereka memahami sebagai sebuah foto yang bagus lewat simbol emoticon yang disediakan Instagram dan kebanggaan sebagai salah satu warga Bekasi seperti yang dikemukakan akun stasyanatalia yang merupakan salah satu pengikut/follower akun Bekasi banget.

Tengara berikutnya yang sering muncul diakun Instagram Bekasi banget dan explore Bekasi adalah Landmark Summarecon Bekasi. Sesuai namanya tengara ini dibangun atas inisiatif perusahaan swasta properti pada tahun 2013 dengan bentuk piramida terbalik setinggi 17 meter yang terbuat dari pipa baja hitam. Apabila dilihat dari konsep yang disampaikan oleh perusahaan ini di websitenya terlihat mereka mencoba membangun identitas sebagai kota mandiri yang seiring perjalanan waktu semakin berkembang besarnya dan memberikan kontribusi positif bagi perusahaan dan lingkungan sekitarnya. Dari terlihat yang dibangun adalah konstruksi identitas yang menguntungkan secara komersial. Akan tetapi bagi pengikut dua akun Instagram ini, tempat ini hanya dilihat sebagai objek atau latar yang indah untuk dijadikan foto dengan banyaknya yang memijit tombol like terhadap foto-foto yang diunggah ke akunakun ini. Seperti yang disampaikan Berger bahwa ketika seorang fotografer memutuskan untuk mengabadikan satu momen, dia menyampaikan satu pesan sederhana yaitu bahwa momen ini paling pantas untuk direkam dibandingkan dengan momen-momen lainnya. Sehingga begitu yang dipilih adalah tengara Summarecon Bekasi berarti tempat ini memiliki pemaknaan yang sangat penting bagi yang mengunggah foto ini maupun bagi followers yang memencet tombol like.

Pemerintah kota Bekasi sendiri mempunyai akun Instagram Pemkot Bekasi yang berisi kegiatan dan program-program yang mereka miliki. Salah satu program yang berhubungan dengan fotografi adalah Pameran Foto Denyut Nadi Kranji. Lewat program ini terlihat mereka memilih objek yang berbeda dibandingkan dengan akun Bekasi Banget dan Explore Bekasi yang banyak memilih objek tengara Bekasi. Objek yang dipilih pameran foto ini adalah Pasar Tradisional Bekasi. Dalam keterangan yang diberikan oleh Kepala Dinas Informatika Statistik dan Persandian (Diskominfostandi) Titi Masrifahati, Didi dari Planet Bekasi, dan Kiki dari APFI Bekasi terlihat ini merupakan suatu usaha untuk mengkonstruksi citra positif Bekasi di media sosial yang cenderung negatif. Bekasi pada tahun 2014 pernah dikonstruksikan oleh pengguna media sosial diantaranya meme yang memberikan pemaknaan bercuaca sangat panas dengan meme gambar matahari yang lebih dekat dari Bekasi daripada dari Bumi. Kemudian juga Bekasi 


\section{Identitas Bekasi dalam Akun Media Sosial Komunitas}

dikonstruksikan sebagai tempat yang jauh dari pusat peradaban dengan meme jangan berkenalan dengan perempuan Bekasi karena jauh untuk berkencan dan juga Bekasi dimeme sebagai tempat yang cocok untuk pengasingan koruptor.

Pemerintah Kota Bekasi sendiri memiliki slogan "Maju, Sejahtera, dan Ihsan". Lewat slogan inilah dibangun Identitas kota Bekasi salah satunya lewat akun media sosial Instagram, Facebook, dan Twitter yaitu@PemkotBekasi. Unggahanunggahan yang muncul di akun-akun lewat foto kegiatan seperti pemusnahan miras hasil operasi Pekat Jaya 2016 yang menunjukan identitas Ihsan yang ingin dibangun. Ihsan sendiri merupakan istilah Bahasa Arab/Islam yang menurut KBBI berarti baik. Pemaknaan Ihsan sendiri dalam Islam menjadi lebih sempit lagi yaitu pada perilaku baik seorang muslim yang mentaati ajaran agamanya. Apabila menggunakan konteks foto pemusnahan miras tadi maka makna Ihsan akan muncul sebagai ketaatan untuk tidak mengkonsumsi dan menyimpan miras dan memusnahkannya adalah sesuatu aktivitas yang dianggap baik dalam Islam.

Selain itu lewat akun
@PemkotBekasi, juga dibangun identitas Bekasi sebagai kota bersejarah. Hal ini terlihat lewat unggahan foto kegiatan Jelajah Bekasi Tempo Doeloe. Acara ini mengajak komunitas sepeda untuk mengunjungi tempat yang dianggap bersejarah oleh pemkot Bekasi yaitu Tugu Alun-Alun Bekasi, Klenteng Hok Lay Kiong, Gedung Papak, Pesantren At-Taqwa, dan Balaikota Bekasi. Lewat pemilihan tempat-tempat yang dikunjungi terlihat ada suatu usaha untuk membangun ingatan kolektif tentang Bekasi yang tidak terlepas dari perjuangan kemerdekaan Indonesia terhadap Belanda ketika melihat Tugu Alun-alun dan Gedung

\footnotetext{
${ }^{10}$ Randy Wirayudha, "Monumen Perjuangan Rakyat Bekasi, Siapa Peduli?," 2018. Diakses tanggal 8 September 2018.
}

Papak. Tugu Alun-alun sendiri diresmikan pada tanggal 5 Juli 1955 sebagai monumen peringatan proklamasi kemerdekaan Indonesia bulan Agustus 1945 dan pendirian kabupaten Bekasi pada bulan Februari 1950 seperti yang tertulis di plakat monument tersebut. Akan tetapi menurut Abdul Khoir $^{10}$ ada satu peristiwa lagi yang tidak tertulis di plakat tersebut yaitu peristiwa peperangan antara para pejuang Bekasi dengan Sekutu beserta NICA/Belanda pada pertengahan Juni 2016. Sedangkan Gedung Papak sendiri dibangun pada tahun 1930 oleh seorang pengusaha Cina bernama Lee Guan Chin. Gedung yang dinamai Papak karena desain atapnya yang rata ini masuk kedalam memori kolektif kesejarahan Bekasi karena pernah dijadikan markas para pejuang Bekasi yang dipimpin oleh $\mathrm{KH}$ Noer Ali ketika berperang melawan Sekutu dan Belanda.

Lewat pemilihan Klenteng Hok Lay Kiong dan pesantren At Taqwa terlihat bahwa ingatan kolektif yang ingin dibangun adalah tentang keberagaman religi dan etnisitas. Klenteng Hok Lay Kiong sendiri merupakan tempat beribadah penganut agama Konghucu yang didominasi etnis Cina sedangkan pesantren At Taqwa merupakan sebuah tempat Pendidikan agama Islam yang siswanya didominasi oleh etnis Bekasi dan Sunda. Klenteng Hok Lay Kiong berdiri sejak abad 18 Masehi yang dibangun oleh etnis Cina yang tinggal di pasar Bekasi Lama/Pasar Proyek. Tempat ini paling ramai dikunjungi ketika tahun baru Cina, kemudian upacara Tabur Sial, maupun acara pukul bedug setiap awal dan akhir bulan purnama. Ketika peristiwa-peristiwa tersebut terjadi komunitas Bekasi banget pernah mengabadikannya lewat kegiatan fotografi yang mereka lakukan di tempat ini sebagai salah satu event gathering yang rutin

https://historia.id/kota/articles/monumenperjuangan-rakyat-bekasi-siapa-peduli-PM1kE 
mereka selenggarakan. Sedangkan Pesantren At Taqwa sendiri sudah ada sejak 1940 setelah pendirinya KH Noer Ali pulang dari Mekah, tetapi secara legal formal pesantren ini berdiri pada 6 Agustus 1956. Bagi anggota komunitas Bekasi Banget maupun Explore Bekasi tempat ini hampir tidak pernah dijadikan objek foto di akunakun ini. Mereka lebih tertarik mengabadikan Masjid Agung Al Barkah ataupun Mesjid Al Azhar Kalimalang Bekasi ketika momen-momen besar Islam seperti Idul Fitri ataupun Maulid Nabi Muhammad SAW. Absennya Pesantren At Taqwa dalam akun komunitas foto ini bisa dilihat sebagai pesan bahwa dalam konstruksi pemaknaan religi Islam Bekasi, pesantren ini bukan bagian dari identitas kota Bekasi. Tetapi bagi akun pemkot Bekasi tempat ini masih mempunyai posisi yang penting terutama karena pendirinya KH Noer Ali merupakan seorang pahlawan nasional sehingga dalam kegiatan Jelajah Bekasi Tempo Doeloe tempat ini menjadi salah satu destinasi yang penting dalam ingatan kolektif kota ini.

\section{SIMPULAN}

Untuk kesimpulan yang bisa diambil dari hasil analisis berdasarkan data-data yang ditemukan sudah mulai terlihat pertanda kontestasi identitas Bekasi dalam akun media sosial Instagram. Kontestasinya sendiri terlihat lewat akun Bekasi banget dan akun explore Bekasi yang cenderung mengedepankan modernitas Bekasi lewat foto-foto tengara yang diunggah diakunakun tersebut. Sedangkan akun pemkot Bekasi cenderung merepresentasikan identitas historis dan agamis yang merupakan bagian dari slogan kota ini yaitu "maju, sejahtera, ihsan".

Adapun saran yang bisa diberikan oleh penelitian ini adalah konstruksi identitas adalah hal yang tidak bisa dipaksakan dan akan selalu berkembang sesuai teori identitas Stuart Hall yang menurut dia akan selalu cair. Selain itu untuk penelitian selanjutnya dapat mengambil objek lain salah satunya bagaimana identitas dikonstruksikan dalam ruang publik selain dari tengara.

\section{DAFTAR PUSTAKA}

Barthes, Roland. "The Photographic Message". In Image, Music, Text. New York: Hill and Wang, 2009.

Benjamin, Walter. "The Work of Art in the Age of Mechanical Reproduction". In Illumination edited by Hannah Arendt. New York: Schocken Books, 1969.

Berger, John. Understanding a Photograph.

New York: Aperture Book Programme, 2013.

Firman, Tommy. "Land Conversion and Urban Development in the Northern Region of West Java, Indonesia." Urban Studies Vol. 34, No. 7 (June 1997), pp. 1027-1046

Gibbs, Martin. "Funeral and Instagram: death, social media, and platform vernacular" Information, Communication \& Society, 2015.Vol. 18, No. 3, 255-268, http://dx.doi.org/10.1080/1369118X.2 014.987152

Hall, Stuart. "The Work of Representation". In Representation: Cultural Representations and Signifying Practices. London: Open University, 1997.

Kusno, Abidin. "Housing the Margin: Perumahan Rakyat and the Future Urban Form of Jakarta". Indonesia No. 94 (October 2012), pp. 23-56 
Lo, Ria Hutabarat. "The City as a Mirror: Transport, Land Use and Social Change in Jakarta", Urban Studies Vol. 47, No. 3 (March 2010), pp. 529555

Madden, Mary. Teens, Social Media, and Privacy. Pew Research Center, 2013. Postill, John, and Sarah Pink. "Social Media Ethnography: The Digital Researcher in a Messy Web." Media International
Identitas Bekasi dalam Akun Media Sosial Komunitas

Australia 145, no. 1 (November 2012): 123-34. doi:10.1177/1329878X1214500114 Wirayudha, Randi. "Monumen Perjuangan Rakyat Bekasi, Siapa Peduli?," 2018. Diakses tanggal 8 September 2018. https://historia.id/kota/articles/monum en-perjuangan-rakyat-bekasi-siapapeduli-PM1kE 